4. Гаркуша Ю.Ф., Черлина Н.А., Манина Е.В. Новые информационные технологии в логопедической работе. // Логопед. 2004. - № 2.

5. Елсакова А. Н., Лисовская Н. Н., Соколова И. В. Использование инновационных технологий в работе учителя-логопеда. // Педагогика: традиции и инновации: материалы $\mathrm{V}$ междунар. науч. конф. (г. Челябинск, июнь 2014 г.). -- Челябинск: Два комсомольца, 2014. C. 33-34.

6. Зинкевич-Евстигнеева Т.Д. Практикум по сказкотерапии / Зинкевич-Евстигнеева Т.Д. - СПб.: Речь, 2013. - 320с.

7. Логопсихологія: навч. посіб. / С. Ю. Конопляста, Т. В. Сак ; за ред. М. К. Шеремет. - К.: Знання, 2010. - 293 с.

DOI https://doi.org/10.30525/978-9934-26-173-2-57

\title{
ОСОБЛИВОСТІ ПОБУДОВИ СОЦІАЛЬНОЇ ВЗАЄМОДІї ДІТЬМИ МОЛОДШОГО ШКІЛЬНОГО ВІКУ З ПОРУШЕННЯМИ ІНТЕЛЕКТУАЛЬНОГО РОЗВИТКУ
}

\author{
Старинська О. В. \\ кандидат психологічних наук, \\ доиент кафедри прикладної психології та логопедї \\ Бердянський державний педагогічний університет \\ Кривунь О. В. \\ директор Бердянської міської гімназї № 3 «Сузір’я» Бердянської \\ міської ради Запорізької області \\ м. Бердянськ, Запорізька область, Україна
}

В процесі навчання, розвитку та виховання індивід накопичує i засвоює соціальний досвід, необхідний для успішної взаємодії 3 оточуючими, що сприяє формуванню і розкриттю його особистості. Але життя і активність людини в соціумі були б неможливі без виникнення певних суб' єктивних зв'язків між членами суспільства, що об'єктивно відбиваються в способах і характері взаємовпливів, які здійснюються людьми один на одного в процесі спільної діяльності і спілкування.

Актуальним завдання сьогодення $\epsilon$ розвиток навичок соціальної взаємодії у дітей 3 особливими освітніми потребами, що $є$ найважливішим фактором соціалізації дитини і компенсації порушень в іiі 
розвитку. Труднощі у відносинах із оточуючими у дітей 3 порушеннях інтелектуального розвитку пов'язані з несформованістю форм спілкування, нерозвиненістю комунікативних навичок, уповільненим емоційно-особистісним розвитком.

Важливо зазначити, що у дітей $з$ порушеннями інтелектуального розвитку зазвичай зустрічаються порушення соціальної взаємодії, що в свою чергу може привести до соціальної дезадаптації дитини. Цим і зумовлена актуальність обраної теми дослідження.

Об'єкт дослідження - соціальна взаємодія дітей молодшого шкільного віку з порушеннями інтелектуального розвитку.

Предмет дослідження - процес формування навичок соціальної взаємодії дітей молодшого шкільного віку 3 порушеннями інтелектуального розвитку.

Будь-який вид соціальної діяльності людей, будь-який соціальний процес складається 3 простих елементів, які відображає поняття «соціальна дія». М.Вебер під соціальною дією розумів дію людини (незалежно від того, чи має вона або внутрішній характер, чи зводиться до невтручання або до терпеливого прийняття), яка за передбаченою дією особи або діючими особами згідно зі своїм змістом співвідноситься 3 дією людей або орієнтується на неї [3]. Зрозуміло, що соціальна дія має дві особливості: по-перше, вона $є$ раціональною та усвідомленою, а подруге, орієнтованою на поведінку інших людей. Очевидно, що, здійснюючи соціальні дії, кожна особистість відчуває на собі дії інших людей. Відбувається обмін діями, або соціальна взаємодія.

Соціальна взаємодія - система взаємозумовлених соціальних дій, за яких дії одного суб'єкта (індивіда, групи, спільноти) одночасно є причиною і наслідком відповідних дій інших. У процесі іiі реалізується соціальна дія партнерів, відбувається взаємне пристосування дій кожного з них, одностайність у розумінні ситуації, усвідомленні іiі смислу дій, певний ступінь солідарності між ними. Можна сказати, що кожну соціальну дію спричинює попередня соціальна дія та водночас вона $є$ причиною наступних дій.

Соціальна взаємодія молодших школярів з порушеннями розумового розвитку також характеризується низкою особливостей, які обумовлені ступенем вираженості дефекту. Діти молодшого шкільного віку 3 порушеннями інтелектуального розвитку в процесі соціальної взаємодії прагнуть привернути увагу до себе, 3 метою позитивної оцінки їх діяльності. Якщо в ході взаємодії дитині не вдається досягти своєї мети, вона свою поведінку ініціює агресію, звертається зі скаргою до дорослих. Така поведінка характеризує агресивну дитину з заниженою самооцінкою, оскільки він не може реалізувати себе в групі однолітків. 
Внаслідок почуття незадоволеності в результаті отримання, на його думку, заниженої оцінки з боку партнерів по спілкуванню дитина бачить у ставленні до себе з боку товаришів ворожий настрій і зневагу, чекає від них підступу. Дитина молодшого шкільного віку з порушеннями інтелектуального розвитку в результаті незадоволеності спілкуванням 3 однолітками часто відчуває тривожність, переживання. Все це може глибоко травмувати дитину. I допомогти дитині молодшого шкільного віку 3 порушеннями інтелектуального розвитку та сформувати у неї навики соціальної взаємодії $є$ першочерговим завданням психологів і педагогів.

У сприятливих умовах група однолітків $є$ для дитини основним джерелом багатьох позитивних емоцій. У ній діти накопичують досвід у взаємодії один з одним. Саме однолітки допомагають дитині молодшого шкільного віку з порушеннями інтелектуального розвитку адекватно оцінити власну поведінку як через порівняння його з поведінкою інших дітей, так і за допомогою оцінок, які дають йому однолітки. Діти молодшого шкільного віку з порушеннями інтелектуального розвитку не передбачають наслідків своєї поведінки, їм важко зрозуміти подальші дії їх співрозмовника, що позначається на нерозумінні зв'язку між тим, що робить дитина зараз і ії наслідками. Тому вони можуть порушувати правила, і часто провокувати конфлікти [4].

Так само діти даної категорії погано можуть визначати різні невербальні реакції, що заважає їм правильно розуміти психологічний стан людини, емоції, які він відчуває, почуття по міміці та жестам. Їм важко правильно інтерпретувати зміст висловлення, оскільки вони не співвідносять його з невербальними реакціями, в яких людина заклала важливий сенс в розумінні сказаного [6].

Діти молодшого шкільного віку 3 порушеннями інтелектуального розвитку не здатні зрозуміти багатозначні слова і також схожі вербальні реакції людини в залежності від конкретного контексту. Так само в них слабкий словниковий запас, мова одноманітна. Все це веде до ускладнень в правильному розумінні мовленнєвих конструкцій в контексті взаємини з людиною. Дані порушення призводять до нерозуміння, провокування конфліктів. При цьому таким дітям важко зрозуміти сенс, який в різних ситуаціях, при спілкуванні з різними людьми означає зовсім різне. Тому вони часто говорять в певній ситуації не те, що потрібно, виявляють нетактовність.

Оскільки у дітей молодшого шкільного віку 3 порушеннями інтелектуального розвитку не виходить стежити за логікою розвитку подій і за поведінкою учасників взаємодії, то це викликає труднощі в розумінні причин такої поведінки тих чи інших учасників взаємодії. Так 
само вони насилу можуть визначати наміри i потреби учасників взаємодії, і це викликає порушення адаптації до ситуації спілкування, а оскільки спілкування і дії протікають досить швидко, то це надає ще більший вплив на адаптацію до ситуації спілкування. Діти молодшого шкільного віку з порушеннями інтелектуального розвитку, найчастіше, не мають інтересу до іншої людини, до проблем групи. Науковці виділяють у таких дітей чотири рівні становлення навичок соціальної взаємодії, кожна з яких залежить від кількох чинників: власне здатності дитини до комунікації, обраного дитиною способу комунікації, мотиву комунікації, розуміння дитиною сенсу комунікації [1].

В експериментальному дослідженні, яке проводилось на базі Бердянської міської гімназії № 3 «Сузір’я» Бердянської міської ради Запорізької області взяли участь дві групи дітей молодшого шкільного віку: експериментальна і контрольна.

В експериментальну групу увійшли діти 3 порушеннями інтелектуального розвитку. Вік дітей $-6-8$ років. У групі 10 дітей, з них 7 хлопчиків і 3 дівчинки. До контрольної групи увійшли нормально розвинені діти молодшого шкільного віку. Вік дітей $-6-8$ років. У групі 10 дітей, 3 них 5 хлопчиків і 5 дівчаток. Крім даних, отриманих при виконанні експериментальних завдань, були проведені бесіди 3 педагогами та іншими фахівцями закладу. Дослідження навичок соціальної взаємодії здійснювалося з використанням наступних методик: методика соціометричного дослідження «Два будиночки» (за Т. Д. Марцинковською); методика Г. Л. Цукерман «Рукавички»; методика «Сходинки» (В.Г. Щур). Серед дітей експериментальної групи 30\% виявили другий рівень розвитку навичок соціальної ваємодії, 40\% - третій та $30 \%$ - четвертий.

Проведене дослідження рівнів сформованості навичок соціальної взаємодії у дітей молодшого шкільного віку 3 порушеннями інтелектуального розвитку свідчить про необхідність цілеспрямованої роботи щодо їх розвитку. Виявлені проблеми в соціальній взаємодії у дітей молодшого шкільного віку 3 порушеннями інтелектуального розвитку в процесі дослідження, визначають пріоритетні напрямки психологічної корекційно-розвиткової роботи.

При визначенні змісту програми корекційно-розвиткової роботи 3 дітей молодшого шкільного віку 3 порушеннями інтелектуального розвитку та вибору методів іiі реалізації необхідно враховувати особливості когнітивного розвитку. 


\section{Література:}

1. Алтухова Т.А. До питання реалізації психолого-педагогічних умов навчання дітей 3 порушеннями інтелекту спільно 3 дітьми, які нормально розвиваються в загальноосвітній школі. URL: http://nbuv.gov.ua/UJRN/znpkp_sp_2012_19(2)_3

2. Бандура Н.I. Корекційно-розвивальна програма спілкування для дітей 3 інтелектуальною недостатністю. Дитина з особливими потребами. 2016. № 2. С. 27 - 31; № 3. С. 27-31.

3. Вебер М. Соціологія. Загальноісторичні аналізи. Політика. Київ: Основи, 1998. 534 с.

4. Гончарук Н.М. Особливості міжособистісних взаємостосунків та спілкування розумово відсталих школярів в умовах шкільної групи. URL: http://nbuv.gov.ua/UJRN/znpkp_sp_2012_20(2)_9

5. Дьякова О.С. Вивчення стану сформованості комунікативних умінь у молодших школярів 3 інтелектуальною недостатністю. URL: http://nbuv.gov.ua/UJRN/ooop_2013_4(2)_14

6. Зелінська К.О. Розвиток комунікативних умінь дітей молодшого шкільного віку 3 інтелектуальними вадами засобами театральної діяльності. URL: http://nbuv.gov.ua/UJRN/Nchnpu_019_2014_26_26 